\title{
Efektivitas Model Pembelajaran Problem Based Learning Berbantuan LKS Terhadap Kemampuan Berpikir Kritis Fisika Siswa SMAN 1 Lingsar Tahun Ajaran 2016/2017
}

\author{
Andi Fatimatul Islamiah $^{\left.1^{*}\right)}$, Satutik Rahayu ${ }^{2)}$, Ni Nyoman Sri Putu Verawati ${ }^{3)}$ \\ ${ }^{1,2 \& 3)}$ Program Studi Pendidikan Fisika, Universitas Mataram \\ *Email: andi.fatima4@gmail.com
}

\section{Article History}

Received: April 2018

Reviewed: May 2018

Published: June 2018

Key Words

Problem Based Learning;

Critical Thingking Ability

Sejarah Artikel

Diterima: April 2018

Direviu: Mei 2018

Dipublikasi: Juni 2018

Kata Kunci:

Problem Based Learning;

Kemampuan berpikir kritis

How to cite this article?

\begin{abstract}
[Title: The Effect of Thinking Aloud Pair Problem Solving Learning Model Toward Student Physics Science Learning Outcomes]. This research aims to know the effectiveness of the learning problem based learning model assisted work sheet for the critical thinking ability of physics students of grade X SMAN 1 Lingsar inacademics year 2016/2017. This was an experiments research that using design research Posttest-Only Control group Design. The population in this research were the whole grade X SMA Negeri 1 Lingsar in academics year 2016/2017. Sampling taken with using cluster random sampling technique with the students of class $X$. MIA. A as experiments class and grade X. MIA. D as controls class. Research hypothesis was analysis with the t-test for one party (the party right). Based on the hypothesis test results obtained $t_{\text {count }}>t_{\text {table }}$ at significance level of $5 \%$, then it can be inferred that the model of learning problem based learning assisted work sheet effective for critical thinking ability of physics students SMAN 1 Lingsar.
\end{abstract}

\begin{abstract}
Abstrak
Penelitian ini bertujuan untuk mengetahui keefektifan model pembelajaran berbasis masalah pembelajaran berbantuan lembar kerja terhadap kemampuan berpikir kritis siswa fisika kelas X SMAN 1 Lingsar tahun akademik 2016/2017. Penelitian ini adalah penelitian eksperimen yang menggunakan penelitian desain Posttest-Only Control group Design. Populasi dalam penelitian ini adalah seluruh siswa kelas X SMA Negeri 1 Lingsar tahun akademik 2016/2017. Pengambilan sampel dilakukan dengan menggunakan teknik cluster random sampling dengan siswa kelas X. MIA. A sebagai kelas eksperimen dan kelas X. MIA. D sebagai kelas kontrol. Hipotesis penelitian adalah analisis dengan uji-t untuk satu pihak (pihak yang berhak). Berdasarkan hasil uji hipotesis diperoleh $t_{\text {hitung }}>t_{\text {tabel }}$ pada taraf signifikansi $5 \%$, maka dapat disimpulkan bahwa model pembelajaran berbasis masalah pembelajaran lembar kerja berbantuan efektif untuk kemampuan berpikir kritis siswa fisika SMAN 1 Lingsar.
\end{abstract}

Islamiah, A., F., Rahayu, S., \& Verawati, N., N., S., P. (2018). Efektivitas Model Pembelajaran Problem Based Learning Berbantuan LKS Terhadap Kemampuan Berpikir Kritis Fisika Siswa SMAN 1 Lingsar Tahun Ajaran 2016/2017. Lensa: Jurnal Kependidikan Fisika, 6(1), 29-36.

\section{PENDAHULUAN}

Perkembangan ilmu pengetahuan dan tekhnologi yang pesat menuntut adanya peningkatan mutu pendidikan. Hal ini sejalan dengan terus dikembangkannya kurikulum pendidikan di Indonesia. Kurikulum pendidikan yang diberikan harus mampu membekali peserta didik dalam mengikuti perubahan dan pertumbuhan di masyarakat yaitu kemampuan berpikir tingkat tinggi, salah satunya yaitu membangun kemampuan berpikir kritis. Hal tersebut sesuai dengan diterapkannya Kurikulum 2013 dalam pembelajaran yang mencakup kompetensi sikap, pengetahuan, dan keterampilan dalam pembelajaran. 
Proses pembelajaran diharapkan dapat menjadi perantara dalam mengembangkan kemampuan berpikir khususnya kemampuan berpikir kritis untuk mencari, menemukan, dan membangun pengetahuan peserta didik secara mandiri. Kemampuan berpikir kritis merupakan kemampuan dasar yang sangat dibutuhkan khususnya pada pembelajaran fisika. Pembelajaran fisika bukan hanya penguasaan kumpulan pengetahuan yang berupa fakta, konsep atau prinsip saja tetapi pembelajarannya berkaitan dengan cara mencari tahu tentang fenomena alam secara sistematis melalui permasalahan yang ada dalam kehidupan sehari-hari. Sehingga, kemampuan berpikir kritis diperlukan peserta didik untuk memecahkan masalah yang dihadapi.

Berdasarkan hasil wawancara yang dilakukan pada salah satu guru pelajaran fisika di SMA Negeri 1 Lingsar diperoleh bahwa guru belum pernah mengukur kemampuan berpikir kritis karena masih terfokus terhadap hasil belajar fisika. Guru tersebut tidak menyadari bahwa sebenarnya telah mengukur kemampuan berpikir kritis. Kemampuan berpikir kritis diantaranya dapat ditunjukkan dari cara peserta didik menganalisis, mensintesis, memecahkan masalah, menyimpulkan dan mengevaluasi suatu permasalahan fisika. Kemampuan berpikir kritis peserta didik masih lemah, hal ini di tunjukkan dari kurangnya pemahaman terhadap permasalahan yang diberikan karena rendahnya daya analisis yang ditunjukkan dari cara mengidentifikasi masalah yang masih rendah. Selain itu, perhitungan peserta didik masih lemah, padahal dalam pembelajaran fisika perhitungan tersebut sangat penting dalam memecahkan masalah. Sehingga, kemampuan berpikir kritis sangat diperlukan karena bermanfaat untuk meningkatkan kemampuan dalam menghubungkan permasalahan fisika dengan kehidupan nyata, untuk itu kemampuan berpikir kritis harus mulai ditekankan dengan cara melatih dan mengukur kemampuan berpikir kritis peserta didik. Belajar untuk berpikir dengan cara kritis analitis dan evaluatif berarti menggunakan proses mental seperti perhatian, kategorisasi, seleksi, dan penilaian. Banyak orang memiliki potensi untuk mengembangkan pemikiran kritis yang lebih efektif tetapi terhambat karena berbagai alasan selain dari kurangnya kemampuan. Berpikirkritis adalah interpretasi dan evaluasi yang terampil dan aktif terhadap observasi dan komunikasi, informasi dan argumentasi (Fisher, 2007).Berpikir kritis adalah sebuah proses sistematis yang memungkinkan siswa untuk merumuskan dan mengevaluasi keyakinan dan pendapat mereka sendiri. Berpikir kritis adalah sebuah proses terorganisasi yang memungkinkan siswa mengevaluasi bukti, asumsi, logika dan bahasa yang mendasari pernyataan orang lain (Johnson, 2010).Pemikir kritis meneliti dengan cermat proses berpikir orang lain untuk mendapatkan pemahaman yang paling lengkap. Mereka berusaha berpikir dengan berurutan dan objektif serta menangguhkan prasangka dan emosi pribadi dalam mencari keyakinan (Alwasilah, 2008).

Berdasarkan beberapa pendapat di atas, peneliti menyimpulkan bahwa kemampuan berpikir kritis adalah kemampuan berpikir tingkat tinggi yang harus dibangun pada peserta didik agar menjadi suatu watak atau kepribadian yang dapat digunakan untuk memecahkan segala persoalan dengan cara menganalisis, mensintesis, memecahkan masalah, mengevaluasi setiap informasi yang diterimanya kemudian menyimpulkannya secara sistematis.

Keterampilan dasar berpikir kritis berpikir kritis diantaranya yaitu: (a) keterampilan berpikir analisis (b) keterampilan berpikir sintesis (c) keterampilan memecahkan masalah (d) keterampilan menyimpulkan (e) keterampilan mengevaluasi atau menilai (Hendra, 2013). Salah satu model pembelajaran yang dapat membangun kemampuan berpikir kritis adalah model pembelajaran problem based learning.

Model pembelajaran tersebut dapat diartikan sebagai suatu konsep yang menjelaskan proses pembelajaran, baik menjelaskan pola pikir maupun pola tindakan (Abidin, 2014). Selain itu, model pembelajaran dapat diartikan sebagai pola yang digunakan untuk penyusunan kurikulum, mengatur materi, dan memberi petunjuk kepada guru di kelas (Suprijono, 2012).Sehingga dapat disimpulkan bahwa model pembelajaran adalah pola atau perencanaan yang digunakan sebagai pedoman dalam merencanakan kegiatan pembelajaran agar tujuan pembelajaran dapat tercapai.Sedangkan problem based learningyaitu model pembelajaran yang menuntut siswa mengerjakan permasalahan autentik untuk menyusun pengetahuan mereka sendiri, mengembangkan inkuiri, dan kemampuan berpikir lebih tinggi, mengembangkan kemandirian, percaya diri, serta siswa menggunakan keterampilannya seperti bekerja sama dalam menyelesaikan masalah (Trianto, 2010). Selain itu, model problem based learning 
merupakan suatu tipe pengelolaan kelas yang diperlukan untuk mendukung pendekatan kontruktivisme dalam pengajaran dan belajar (Hariyanto, 2012).

Model problem based learning adalah model pembelajaran yang menggunakan permasalahan pada dunia nyata sebagai media pembelajarannya. Masalah yang dikemukakan kepada siswa harus dapat membangkitkan pemahaman siswa terhadap masalah, kesadaran adanya kesenjangan, pengetahuan, tujuan keinginan memecahkan masalah, dan persepsi bahwa mereka mampu memecahkan masalah tersebut (Rusman, 2011).Berdasarkan beberapa pendapat di atas, peneliti menyimpulkan bahwa model pembelajaran problem based learning adalah pembelajaran yang di awali dari suatu permasalahan yang digunakan sebagai sarana untuk investigasi peserta didik. Permasalah yang di sajikan di awal pembelajaran merupakan masalah yang autentik dan bermakna. Setiap peserta didik ataupun kelompok harus menyelesaikan permasalahanpermasalahan tersebut secara mandiri. Dengan berusaha memecahkan permasalahan secara mandiri, diharapkan peserta didik mampu mendapatkan pengetahuannya dengan lebih bermakna. Hal ini diperkuat dengan hasil penelitian Rahmawati et al. (2015) yang menyatakan bahwa model pembelajaran problem based learning efektif untuk meningkatkan kemampuan berpikir kritis dan hasil belajar peserta didik. Hal ini karena, model pembelajaran problem based learning dapat melatih kemampuan berpikir kritis peserta didik dalam menyelesaikan masalah, menarik minat peserta didik dalam pembelajaran dengan adanya interaksi antara peserta didik untuk mencari solusi, dan menuntut peserta didik untuk terlibat aktif dalam proses pembelajaran. Begitu juga menurut Azmi (2016) Model pembelajaran berbasis masalah memberikan kesempatan kepada semua siswa untuk aktif dalam proses pembelajaran, terlebih lagi untuk menyelesaikan permasalahan yang disedikan dalam proses pembelajaran dengan cara melakukan eksperimen dan diskusi sehingga siswa dapat membuktikan sendiri dengan melakukan sendiri proses percobaan untuk membuktikan serta melakukan diskusi untuk menyelesaikan permasalahan yang telah disediakan dalam Lembar Kerja Siswa (LKS) dan Lembar Diskusi Siswa (LDS), Hal ini tentunya memberikan pengaruh terhadap hasil belajar fisika siswa yang dapat dibuktikan dengan nilai rata-rata kedua sampel berada diatas KKM.

Proses pembelajaran yang baik harus mampu memberikan kesempatan kepada peserta didik untuk berperan aktif dalam setiap pembelajaran yang dilakukan. Keaktifan dan kemandirian peserta didik harus tampak dalam setiap proses pembelajaran, maka dibutuhkan bantuan sumber belajar. Lembar Kerja Siswa (LKS) merupakan salah satu alternatif sumber belajar yang dapat diterapkan karena dapat membantu peserta didik untuk menambah informasi tentang konsep yang di pelajari melalui kegiatan belajar secara sistematis.LKS biasanya berupa petunjuk, langkah untuk menyelesaikan suatu tugas, suatu tugas yang diperintahkan dalam lembar kegiatan harus jelas kompetensi dasar yang akan dicapainya.Selain itu, LKS adalah panduan siswa yang digunakan untuk melakukan kegiatan penyelidikan dan pemecahan masalah (Trianto, 2010).Sehingga dapat disimpulkan bahwa LKS adalah lembar kerja yang berisi permasalahan untuk mengasah kemampuan berpikir kritis peserta didik yang dapat mempermudah proses pembelajaran.

Berdasarkan uraian tersebut model pembelajaran problem based learning merupakan salah satu model pembelajaran yang paling efektif untuk meningkatkan keaktifan dan meningkatkan kemampuan berpikir kritis fisika siswa. Salah satunya dengan berbantuan LKS. Berdasarkan uraian di atas, maka peneliti tertarik untuk melakukan penelitian berjudul "Efektivitas Model Pembelajaran Problem Based Learning berbantuan LKS terhadap Kemampuan Berpikir Kritis Fisika Siswa SMAN 1 Lingsar Tahun Ajaran 2016/2017".

\section{METODE}

Jenis penelitian ini adalah true experimental.Dikatakan true eksperimental karena peneliti dapat mengontrol semua variabel luar yang mempengaruhi jalannya eksperimen (Sugiono, 2014). Desain penelitian yang digunakan yaitu Posttest-Only Control Design. Penelitian ini dilaksanakan mulai bulan Januari 2016 sampai dengan bulan Januari 2017 di SMAN 1Lingsar. Populasi dalam penelitian ini adalah seluruh siswa kelas X SMA Negeri 1Lingsar. Sampel dalam penelitian yang digunakan yaitu kelas X MIA.A sebagai kelas eksperimen dan kelas X MIA.D 
sebagai kelas kontrol. Teknik pengambilan sampel dalam penelitian ini yaitu dengan cluster random sampling.

Instrumen yang digunakan dalam penelitian ini adalah tes uraian. Sebelum diberikan pada siswa, instrumen diujicobakan terlebih dahulu. Uji coba instrumen pada penelitian ini meliputi uji validitas, uji reliabilitas, tingkat kesukaran dan daya beda.Data hasil kemampuan berpikir kritis yang terkumpul kemudian dianalisis menggunakan uji prasyarat analisis yaitu uji homogenitas dengan menggunakan Uji $\mathrm{F}$, uji normalitas dengan menggunakan Uji ChiKuadratdan uji hipotesisdengan menggunakan Uji t pihak kanan dengan taraf signifikan 5\%.

Tingkatkemampuan berpikir kritis siswa dapat dianalisis secara deskriptif dengan persentase untuk menggambarkan tingkat pencapaian tiap indikator kemampuan berpikir kritis.

$$
\text { nilai }=\frac{\text { skor yang diperoleh }}{\text { skor maksimal }} \times 100
$$

Setelah diperoleh hasil persentase kemampuan berpikir kritis siswa, peneliti menentukan kategori kemampuan berpikir kritis siswa.Pemberian kategori bertujuan untuk mengetahui kualifikasi persentase kemampuan berpikir kritis siswa. Adapun kategori kemampuan berpikir kritis dibedakan menjadi 4 kategori seperti Tabel 1.

Tabel 1. Pedoman Kategori Berpikir Kritis

\begin{tabular}{ll}
\hline Skala Perolehan & \multicolumn{1}{c}{ Kategori } \\
\hline $81,25<\mathrm{x} \leq 100$ & Sangat Kritis \\
$62,50<\mathrm{x} \leq 81,25$ & Kritis \\
$43,75<\mathrm{x} \leq 62,50$ & Kurang Ktitis \\
$25,00<\mathrm{x} \leq 43,75$ & Sangat Kurang Kritis \\
\hline
\end{tabular}

(Yuliati, 2011)

\section{HASIL DAN PEMBAHASAN}

Penelitian ini dilakukan di SMAN 1Lingsar dengan menggunakan dua kelas sebagai sampel. Sampel pertama adalah kelas MIA.A sebagai kelas eksperimen yang diberi perlakuan menggunakan model pembelajaranproblem based learning berbantuan LKS dan kelas X MIA.D kelas kontrol yang diberikan perlakuan menggunakan model konvensional yang biasa diterapkan. Penelitian ini dilakukan untuk mengetahui efektivitas model pembelajaran problem based learning berbantuan LKS terhadap kemampuan berpikir kritis fisika siswa SMAN 1Lingsar tahun pelajaran 2016/2017.

Data hasil tes kelas eksperimen dan kelas kontrol terdiri dari hasilpost-test. Post-test merupakan tes yang dilakukan setelah perlakuan diberikan kepada kelas eksperimen maupun kelas kontrol yang bertujuan untuk mengetahui pengaruh perlakuan yang diberikan kepada kelas eksperimen yang berupa model pembelajaranproblem based learning berbantuan LKS. Hasil posttest kelas eksperimen dan kelas kontrol disajikan pada Tabel 2 dan Gambar 1 di bawah ini.

Tabel 2.Data Hasil Post-test Kelas Eksperimen dan Kelas Kontrol

\begin{tabular}{lll}
\hline Komponen & Kelas Eksperimen & Kelas Kontrol \\
\hline Jumlah siswa & 25 & 26 \\
\hline Nilai tertinggi & 92,86 & 85,71 \\
\hline Nilai terendah & 46,43 & 46,43 \\
\hline Rata-rata & 70,29 & 61,54 \\
\hline Standar deviasi & 8,97 & 10,13 \\
\hline Varians & 84,44 & 102,63 \\
\hline Uji homogenitas & & Homogen \\
\hline Uji normalitas & Normal & Normal \\
\hline Uji hipotesis & $t_{\text {hitung }}>t_{\text {tabel }}$, & \\
& $\mathrm{H}_{0}$ ditolak dan $\mathrm{H}_{\mathrm{a}}$ diterima & \\
\hline
\end{tabular}




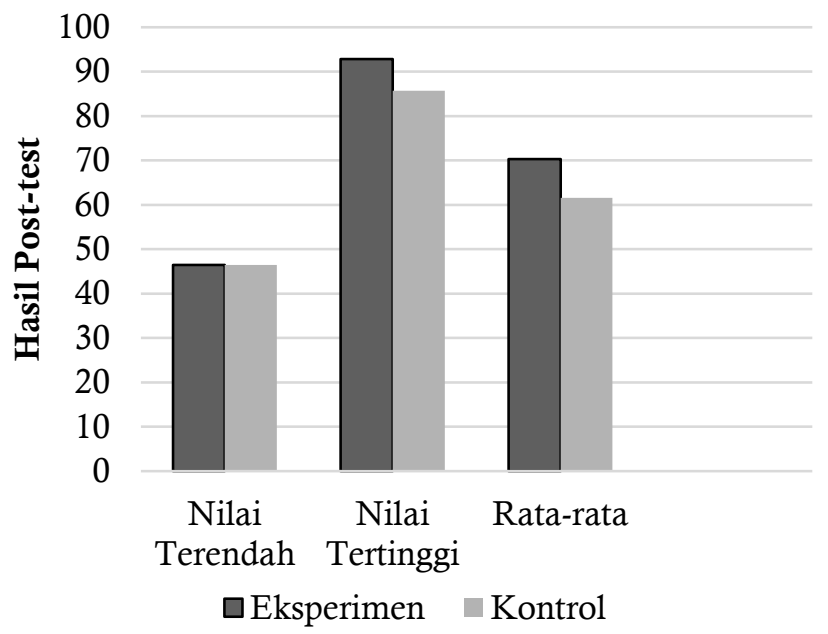

Gambar1. Nilai Post-test Kelas Eksperimen dan Kelas Kontrol

Data hasil kemampuan berpikir kritis siswa kelas eksperimen dan siswa kelas kontrol yang dikelompokkan ke dalam jenjang kualifikasi, maka persentase kemampuan berpikir kritis siswa kelas eksperimen dan siswa kelas kontrol yang dapat dilihat secara rinci pada Tabel 3 dan Gambar 2 dibawah ini.

Tabel 3.Data Hasil Kemampuan Berpikir Kritis Siswa

\begin{tabular}{lll}
\hline Komponen & Kelas Eksperimen & Kelas Kontrol \\
\hline Sangat tidak kritis & $0 \%$ & $0 \%$ \\
\hline Kurang Kritis & $12 \%$ & $46 \%$ \\
\hline Kritis & $72 \%$ & $50 \%$ \\
\hline Sangat Kritis & $16 \%$ & $4 \%$ \\
\hline
\end{tabular}

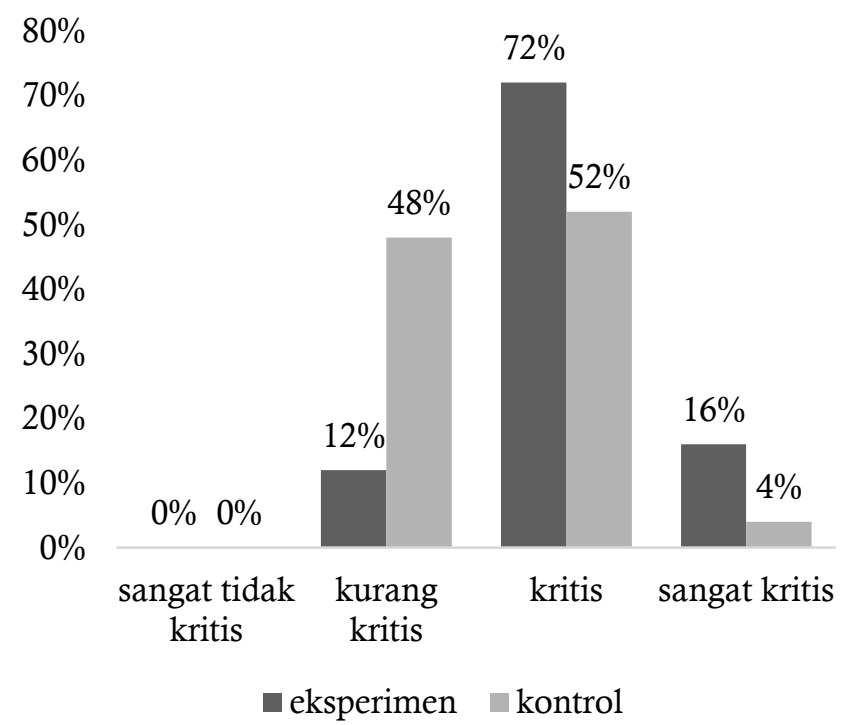

Gambar 2. Diagram Batang Kategori Kemampuan Berpikir Kritis Pada Kelas Eksperimen dan Kelas Kontrol

Berdasarkan data hasil posttest kemampuan berpikir kritis siswa kelas eksperimen dan kemampuan berpikir kritis siswa kelas kontrol di setiap indikator dapat dilihat pada Tabel 4 dan Gambar 3 berikut ini. 
Tabel 4. Data Setiap Indikator Kemampuan Berpikir Kritis Siswa

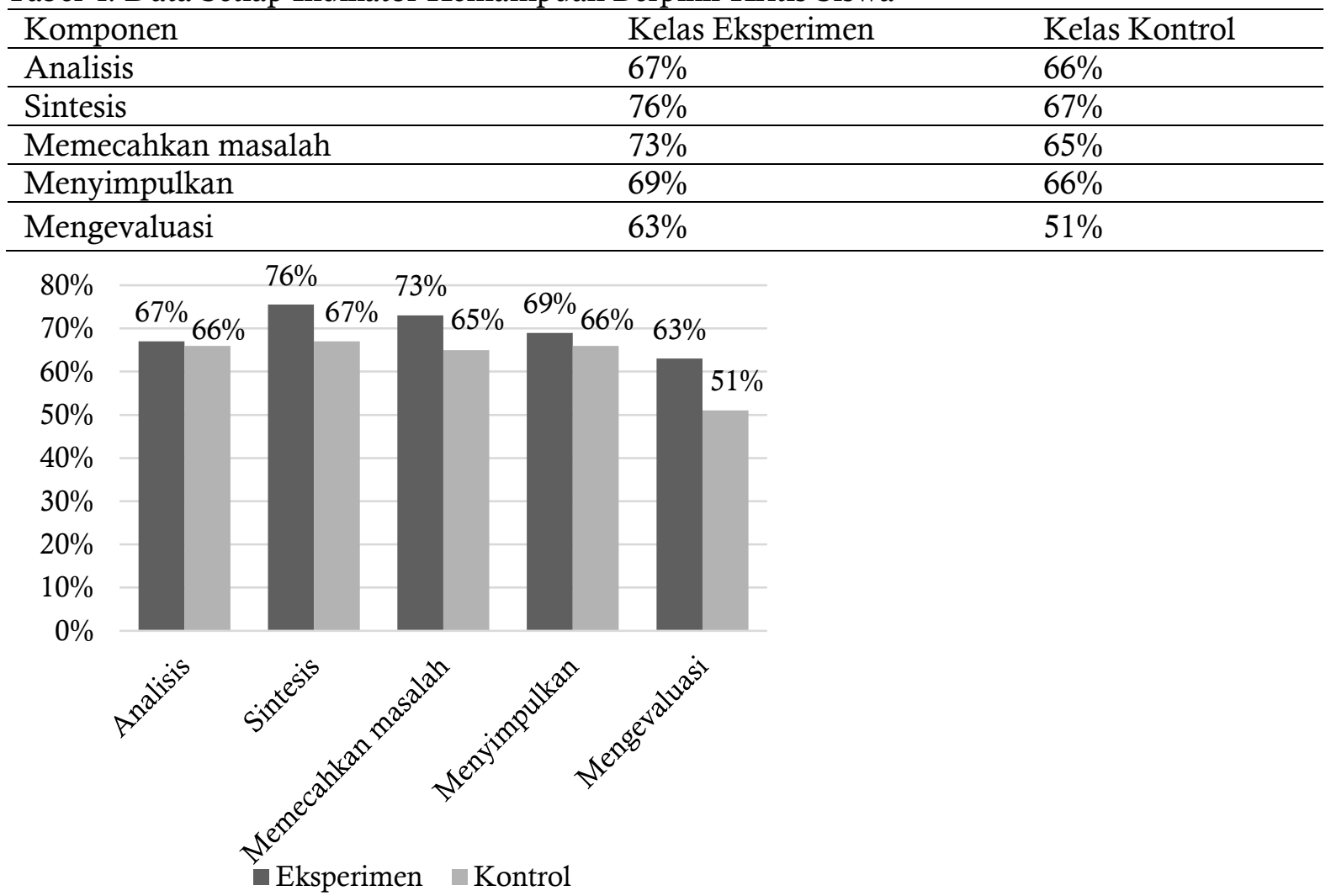

Gambar 3. Nilai Kemampuan Berpikir Kritis Siswa Kedua Kelas Sampel di Setiap Indikator Kemampuan Berpikir Kritis

Berdasarkan hasil penelitian menunjukkan adanya perbedaan rataan nilai siswa pada kelas eksperimen dan kelas kontrol. Padarekapitulasi nilai siswa yaitunilai rata-rata siswa kelas eksperimen 70,29dengan nilai tertinggi 92,86 dan nilai terendah 46,43. Sedangkan nilai rata-rata kelas kontrol diperoleh nilai tertinggi 85,71 dan terendah 46,43 dengan rata-rata 60,54. Berdasarkan uji statistik (uji-t) yang telah dilakukan, harga $t_{\text {hitung }}=2,36$. Harga ini lebih besar dari harga $t_{\text {tabel }}=1,678$. Hal ini menunjukkan bahwa terdapat pengaruh positif terhadap kemampuan berpikir kritis siswa yang mengikuti model pembelajaran problem based learning berbantuan LKS, dimana rata-rata kemampuan berpikir kritis siswa secara keseluruhan ataupun pada setiap indikator kemampuan berpikir kritis menunjukkan bahwa kemampuan berpikir kritis pada kelas eksperimen lebih tinggi dibandingkan kelas kontrol. Dengan kata lain, model pembelajaran problem based learning berbantuan LKS lebih efektif terhadap kemampuan berpikir kritis siswa dari pada model pembelajaran konvensional.

Perbedaan kemampuan berpikir kritis siswa tersebut disebabkan oleh adanya pemberian perlakuan yang tidak sama antara kelas eksperimen dengan kelas kontrol. Kelas eksperimen diberikan perlakuan khusus yakni menggunakan model pembelajaranproblem based learning berbantuan LKS, sedangkan kelas kontrol menggunakan model pembelajarankonvensional.

Model pembelajaran problem based learning berbantuanLKS dalam proses pembelajarannya dapat menarik minat serta rasa ingin tahu siswa untuk menyelesaikan masalah-masalah yang diberikan dalam bentuk LKS. Model pembelajaran problem based learning memiliki 5 tahapan dengan setiap tahapan tersebut mendukung siswa agar dapat mengembangkan kemampuan berpikir kritis. Tahap (1) yaitu mengorganisasikan siswa kepada masalah sesuai dengan dunia nyata siswa, kemampuan berpikir kritis siswa yang dikembangkan pada tahap ini yaitu menganalisis suatu masalah yang dapat ditunjukkan dari respon yang diberikan siswa. Respon yang ditunjukkan siswa pada kelas eksperimen lebih baik dibandingkan kelas kontrol yang menggunakan model pembelajaran konvensional karena komunikasi antara siswa dengan siswa ataupun siswa dengan guru berjalan lancar. Tahap (2) yaitu mengorganisasikan siswa mandiri 
maupun dalam kelompok-kelompok untuk belajar, dalam pembelajarannya siswa dibagi menjadi 5 kelompok dimana setiap kelompok beranggotakan 5 orang. Setiap kelompok dituntut untuk belajar bekerja sama dalam menyelesaikan masalah-masalah yang diberikan. Tahap (3) yaitu membantu penyelidikan mandiri ataupun kelompok, dalam tahap ini siswa didorong untuk mengumpulkan informasi agar dapat menyelesaikan masalah-masalah yang diberikan. Indikator kemampuan berpikir kritis yang dapat dikembangkan pada tahap ini yaitu menganalisis, mensintesis dan memecahkan masalah karena siswa ditekankan untuk mengasah kemampuan berpikir kritisnya dengan berpikir secara terbuka agar dapat menganalisis, mensintesis, dan memecahkan masalah yang diberikan. Tahap (4) yaitu mengembangkan dan mempresentasikan hasil karyanya, indikator kemampuan berpikir kritis yang dapat dikembangkan yaitu dapat menyimpulkan suatu permasalahan karena siswa pada tahap ini dapat merencanakan dan menyajikan hasil karyanya baik secara lisan atau tulisan dengan cara memaparkan hasil diskusinya. Tahap (5) yaitu menganalisis dan mengevaluasi pembelajaran terkait hasil diskusi yang dipaparkan. Indikator kemampuan berpikir kritis yang dapat dikembangkan pada tahap ini yaitu menganalisis dan mengevaluasi suatu permasalahan karena siswa dituntut untuk menemukan keterkaitan masalah yang telah dipecahkan dengan konsep materi yang dikuasai. Kelima tahapan pada model pembelajaran problem based learning tersebut efektif untuk meningkatkan kemampuan berpikir kritis karena indikator kemampuan berpikir kritis dapat tercapai. Hal ini yang mendasari model pembelajaran problem based learning berbantuan LKS efektif digunakan terhadap kemampuan berpikir kritis siswa.

Hal ini berbeda dengan pembelajaran di kelas kontrol yaitu menggunakan model pembelajaran konvensional. Pada pembelajaran tersebut, guru dianggap sebagai sumber utama pembelajaran, sedangkan siswa hanya menjadi penerima pelajaran yang diberikan oleh guru tanpa memerlukan peralatan khusus. Kemampuan berpikir kritis pada proses pembelajaran tersebut tidak tidak lebih efektif terhadap kemampuan berpikir kritis karena data kemampuan berpikir kritis pada siswa kelas eksperimen lebih tinggi dibandingkan kelas kontrol. Adapun kemampuan siswa dalam berpikir kritis pada kelas eksperimen terdiri dari $16 \%$ siswa berkemampuan berpikir dengan sangat kritis, 72\% siswa berkemampuan berpikir dengan kritis, $12 \%$ siswa berkemampuan berpikir dengan kurang kritis, dan $0 \%$ siswa berkemampuan berpikir dengan sangat tidak kritis. Sedangkan pada kelas kontrol, kategori kemampuan berpikir kritis siswa terdiri dari $4 \%$ siswa berkemampuan berpikir dengan sangat kritis, $50 \%$ siswa berkemampuan berpikir dengan kritis, 46\% siswa berkemampuan berpikir dengan kurang kritis, dan $0 \%$ siswa berkemampuan berpikir dengan sangat tidak kritis. Hal ini karena, siswa hanya menerima materi apa adanya tanpa mengumpulkan informasi terlebih dahulu terkait materi yang diajarkan. Selain itu, komunikasi baik antara siswa dengan siswa maupun antara siswa dengan guru tidak berjalan karena siswa cendrung pasif dalam kegiatan pembelajarannya. Hal inilah yang menyebabkan pembelajaran konvensional tersebut tidak efektif digunakan terhadap kemampuan berpikir kritis siswa.

Hasil ini sesuai dengan hasil penelitian Rahmawati et al. (2015) yang menyatakan bahwa model pembelajaran problem based learning efektif untuk meningkatkan kemampuan berpikir kritis siswa karena, model pembelajaranproblem based learning dapat melatih kemampuan berpikir kritis siswa dalam menyelesaikan masalah, menarik minat siswa dalam pembelajaran dengan adanya interaksi antara siswa untuk mencari solusi, dan menuntut siswa untuk terlibat aktif dalam proses pembelajaran. Selain itu, Santoso et al. (2015) juga menyatakan bahwa model pembelajaran berbasismasalah berbantuan media komputer berpengaruh terhadap kemampuan berpikir kritis siswa karena, selama proses pembelajaran siswa di tuntut untuk memecahkan masalah yang diberikan dan kemudian menjelaskannya sesuai dengankonsepnya, hal ini sejalan dengan Fatimah (2016) yang menyatakan bahwa Dengan digunakan model pembelajaran berbasis masalah dengan strategi konflik kognitif, akan membuat peserta didik lebih aktif sehingga kemampuan berpikir kritisnya lebih tinggi dibandingkan dengan pembelajaran dengan model konvensional, begitu juga menurut Herayanti (2015) Data penelitian menunjukkan bahwa terjadi peningkatan keterampilan berpikir kritis pada kedua kelas dengan persentase yang berbeda. Untuk kelas eksperimen peningkatan terting giterjadi pada indikator berkategori Kemampuan menemukan persamaan dan perbedaan sebesar $40 \%$. Berdasarkan uraian diatas 
peneliti menyimpulkan bahwa model pembelajaran problem based learning berbantuan LKS efektif terhadap kemampuan berpikir kritis siswa.

\section{KESIMPULAN}

Berdasarkan hasil penelitian yang telah dilaksanakan, analisis data, dan uji hipotesisi pada taraf signifikansi 5\%dan pembahasan maka dapat disimpulkan bahwa model pembelajaran problem based learning berbantuan LKS efektif terhadap kemampuan berpikir kritis fisika siswa SMAN 1 Lingsar tahun ajaran 2016/2017.

\section{SARAN}

Perlu penelitian lanjutan terhadap indikator analisis dan menyimpulkan, mengingat kedua indikator tersebut tidak berbeda signifikan antara kelas eksperimen dan kelas kontrol.

\section{DAFTAR PUSTAKA}

Abidin, Y. (2014). Desain Sistem Pembelajaran dalam Konteks Kurikulum 2013. Bandung: PT. Refika Aditama.

Alwasilah, C. (2008). Contextual Teaching \& Learning Menjadikan Kegiatan Belajar-Mengajar Mengasikkan dan Bermakna.Bandung: MLC.

Azmi, M. K., Rahayu, S., \& Hikmawati, H. (2017). Pengaruh Model Problem Based Learning dengan Metode Eksperimen dan Diskusi Terhadap Hasil Belajar Fisika Ditinjau dari Sikap Ilmiah Siswa Kelas X MIPA SMA N 1 Mataram. Jurnal Pendidikan Fisika dan Teknologi, 2(2), 86-94.

Fatimah, N., Gunawan, G., \& Wahyudi, W. (2017). Pembelajaran Berbasis Masalah Dengan Strategi Konflik Kognitif Terhadap Penguasaan Konsep Dan Kemampuan Berpikir Kritis Fisika Siswa Kelas XI SMKN 1 Lingsar Tahun Pelajaran 2015/2016. Jurnal Pendidikan Fisika dan Teknologi, 2(4), 183-190.

Fisher, A. (2007). Berpikir Kritis: Sebuah Pengantar. Jakarta: Erlangga.

Hariyanto, M.S \& Warsono, M. S. (2012). Pembelajaran Aktif. Bandung: PT. Remaja Rosdakarya.

Hendra, S. (2013). Cara Belajar Orang Genius Study Hard Belumlah Cukup Tanpa Didukung Study Smart. Jakarta: PT Elex Media Komentindo.

Johnson, E. B. (2010). Contextual Teaching \& Learning Menjadikan Kegiatan Belajar-Mengajar Mengasyikan dan Bermakna. Bandung: Kaifa.

Herayanti, L., \& Habibi, H. (2017). Model Pembelajaran Berbasis Masalah Berbantuan Simulasi Komputer untuk Meningkatkan Keterampilan Berpikir Kritis Calon Guru Fisika. Jurnal Pendidikan Fisika dan Teknologi, 1(1), 61-66.

Rahmawati, D., Sudarmin., \& Novi R.D. (2015). Efektivitas Problem Based Learning (PBL) pada Tema Bunyi dan Pendengaran berbantuan Alat Peraga Tiga Dimensi terhadap Kemampuan Berpikir Kritis Siswa SMP. Unnes Science Education Journal.4(3), 1031-1040.

Rusman. (2011). Model-model Pembelajaran Mengembangkan Profesionalisme Guru. Jakarta: PT. Prajakrafindo Persada.

Santoso, R., Darmadi., \& Darsikin. (2015). Pengaruh Model Pembelajaran Berbasis Masalah berbantuan Media Komputer terhadap Kemampuan Berpikir Kritis Siswa SMA Negeri 5 Palu. Jurnal Pendidikan Fisika Tadulako. 4(1), 39-44.

Sugiyono. (2014). Metode Penelitian Pendidikan Pendekatan Kuantitatif, Kualititatif, dan R\&D. Bandung: Alfabeta.

Suprijono, A. (2012). Cooperative Learnig Teori dan Aplikasi Paikem. Yogyakarta: Pustaka Pelajar.

Trianto. (2010). Mendesain Model Pembelajaran Inovatif-Progresif. Jakarta: Kencana Media Group.

Trianto. (2010). Model-model Pembelajaran Inovatif Berorientasi Konstruktivistik. Jakarta: Prestasi Pustaka.

Yuliati, D.I., Yulianti, D., \& Khanafiyah, S. (2011). Pembelajaran Fisika Berbasis Hands On Activities Untuk Menumbuhkan Kemampuan Berpikir Kritis dan Meningkatkan Hasil Belajar Siswa SMP. Jurnal Pendidikan Fisika Indonesia. 7, 23-27. 